\title{
THE SOCIAL ASPECTS OF THE TREATMENT OF SPINAL CORD INJURED PATIENTS IN ISRAEL
}

\author{
By N. Rosman, M.Ph, A. Ohry, M.D. and R. Rozin, M.D. \\ The Sir Ludwig Guttmann Spinal Cord Injury Centre, The Neurological \\ Rehabilitation Department, The Chaim Sheba Medical Center, Tel Hashomer, Israel
}

\begin{abstract}
The great importance of the social worker's special role in the treatment of spinal cord injury patients is stressed, and this is brought out in this paper with reference to the particular social structure in Israel relating to the rehabilitation of the disabled.
\end{abstract}

Key words: Spinal cord injury; Rehabilitation; Social aspects.

\section{Introduction}

ONE of our society's important values is the individual's right to the fulfilment of his or her basic needs. Permanent disabilities endanger a person's capacity for selffulfilment, for wage earning and for performing positive social roles. The aim of the process of rehabilitation is to overcome these difficulties.

Spinal cord injuries are traumatic events, often happening to young productive adults. All of these patients require long, multidisciplinary treatment in which the social worker has a very important role, both during the acute and the later phases.

\section{The Medical Social Worker within the Spinal Unit}

Immediately after injury the patient undergoes a sudden and total change: he has become completely dependent, usually feeling helpless and depressed. During that period, the social worker (along with the medical and paramedical staff), supports and encourages the patient, letting him express his feelings and providing understanding for his self-centred view of his new situation. At the same time the social worker contacts the patient's family, supports them and explains the disability and its future implications. He helps the family on different levels so that they can face this unexpected and difficult challenge. Later, the patient's rights to financial compensation come into focus. Here the social worker has to decide whether the patient has sufficiently adjusted in order to participate actively in this often bureaucratic and tiresome process.

\section{The Spinal Cord Patient's Legal Rights}

In Israel the spinal cord injured patient will turn to different authorities for compensation according to the cause of his injury, wounds sustained during military service or hostilities, work or traffic accident, disease or birth defect. Each legal framework provides a different level of compensation according to different budgets, which will dictate the span of services provided. The social worker is thus the link between the patient and the relevant institution. Prior to the patient's discharge from hospital the medical social worker gradually will be replaced by a

* Requests for reprints to: Dr Ohry. 
social worker from the agency which will provide rehabilitation services from then on.

We would like to present briefly two of these institutions which care for a large number of spinal cord injured patients in Israel.

\section{Ministry of Defence: Department of Rehabilitation}

Disabled war veterans have a special social significance in Israel and practically almost every family has one or more members of the family serving in the army. The disabled one's plight provoking deep emotional involvement on the part of the general public. Other disabled groups benefit from the situation, gaining improvements in the wake of the war veterans. The law concerning their rights came into effect in 1949 and has been amended 17 times, constantly improving their situation and raising the relevant budgets. The high standard of the rehabilitation services for war veterans has an important positive influence on the soldiers' morale and they know they will be looked after if something happens to them. The law includes medical treatment in Israel and abroad, a pension, suitable housing, vocational studies or the learning of a profession, transportation and assistance in finding a job. All men and women in the army are entitled to these services, whatever their rank and duties.

Completely spinal-cord-injured patients receive large pensions, which unfortunately may cause them not to work, although additional earnings are income tax free. Tetraplegics are also entitled to a personal escort. In housing, the trend is towards suitable individual flats or houses and not collective housing specifically for the disabled. In transportation the preference is for self-driven cars, even for tetraplegics, with the relevant technical adjustments.

\section{The National Insurance Institute}

\section{The Law on Labour Accidents or Deaseases}

Since work represents an essential value in our society the law on victims of work accidents provides for the rehabilitation of spinal cord injuries occurring during or as a result of work. This law is enacted by the National Insurance Institute, which provides monthly pensions, grants for housing and transportation, as well as for technical aids. The patient is entitled to full medical care (in- and outpatient services), medical aids, vocational counselling and job placement.

\section{The Law on General Disability}

This law concerns the loss of the wage-earning capacity and proper functioning, either by accident or by disease, both for working people and for housewives. The loss of the wage-earning capacity must amount to at least 50 per cent for the person to receive a pension. Severely spinal-cord-injured patients are also entitled to nursing care at home and transportation allowances. Other services for all concerned include vocational counselling, studies or professional training and assistance in job placement.

\section{The Law on Disabled Children}

This law concerns children living at home with their parents and needing assistance in A.D.L. and in schooling, depending on the parents' income. 


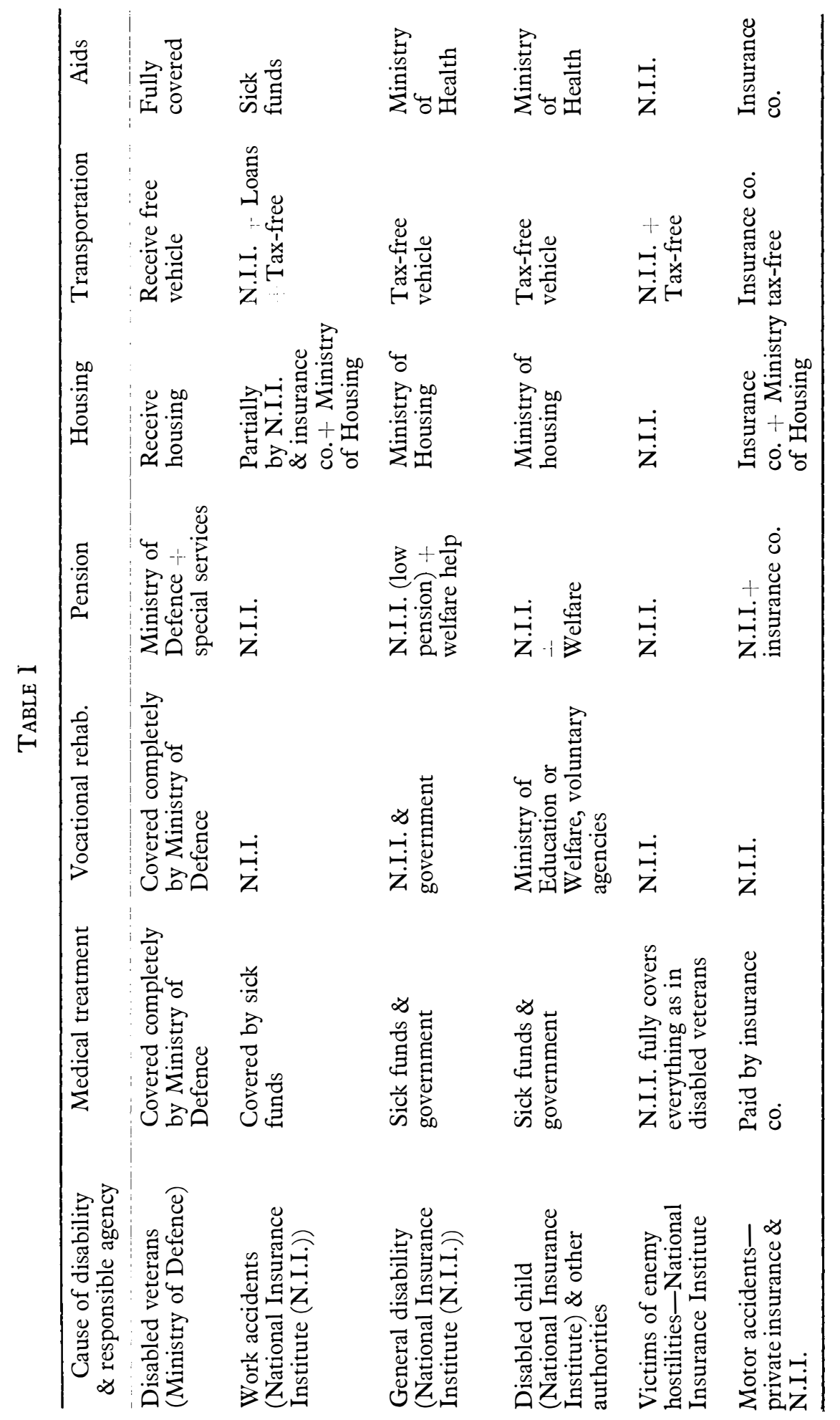




\section{The Law on Victims of Hostilities}

This law is also enacted by the National Insurance Institute and concerns victims of hostile actions by enemy elements in Israel and abroad. The law provides complete assistance to the victims in the same way as the Ministry of Defence looks after disabled war veterans.

Conceptually all these laws show a common concern for the optimal rehabilitation of the disabled, whatever the cause of their disability according to limitations of different laws as described.

\section{Discussion}

The role of the social worker in the spinal injuries centre has various aspects, each demanding different abilities and knowledge. The patient and family care in the acute and subacute stages of the injury both require individual counselling and family therapy, involving the social worker in long meetings and talks. This procedure is time-consuming and the case load of the social worker must necessarily be limited. The social worker should have training in psychology, in individual counselling and in group therapy.

On the other hand the practical problems of helping the injured and his family deal with the various agencies in clarifying their rights (see Table I) are highly technical and systematic and demand an ability to deal with bureaucracy. As shown above there are great differences in the rights of individuals according to the cause of injury and the agency responsible for the ensuing care, e.g. war injury, work or car accidents. Nevertheless, the outcome of the injury and the patient's resulting needs are similar irrespective of the cause of injury. Filling the gap between the needs and the aid provided to the injured is a difficult task which sometimes the social worker, despite his best efforts, is unable to fulfil.

\section{SUMMARY}

The paper presents the rehabilitation framework of spinal cord injured patients in the Sir Ludwig Guttman Centre in Israel. The social worker's special role in our centre is described, from the beginning of his work just after the patient's admission. A trusting relationship is established between the patient and the social worker throughout hospitalisation and subsequently. The social worker also deals with the special needs of the patient's family, providing emotional support and information on legal rights, etc.

We present the specific social structure of Israel in relation to the rehabilitation of the disabled as well as the different official agencies providing services for them. There are considerable differences between the benefits provided by the various agencies for the needs of the spinal-cord injured. As the needs of the injured are the same, irrespective of the cause of injury, the task of the social worker is, therefore, extremely difficult.

\section{RÉSUMÉ}

Ce travail présente le cadre socio-légal de la réadaptation des traumatisés de la moëlle épinière au Centre 'Sir Ludwig Guttmann' en Israël. Le rôle particulier de l'assistant social dans notre centre est décrit, depuis le début de son travail, peuaprès l'admission du patient. Une relation de confiance s'établit entre le patient et l'assistant social tout au long de l'hospitalisa- 
tion ainsi que par la suite. L'assistant social s'occupe également des besoins particuliers de la famille du malade, à laquelle il procure son soutien moral et les informations sur les prérogatives légales, etc.

Nous présentons la structure sociale spécifique en Israël en ce qui concerne la réadaptation des handicapés, ainsi que les différentes agences officielles qui les desservent. Il existe des différences considérables entre les services procurés par les différentes agences. Comme les besoins des traumatisés de la moëlle épinière sont les mêmes quelle que soit la cause du traumatisme, le tâhe de l'assistant social est extrêmement difficile.

\section{ZUSAMMENFASSUNG}

Diese Arbeit stellt den Rehabilitationsrahmen für Rückenmarkverletzte in dem Sir Ludwig Guttmann Zentrum in Israel vor. Die spezielle Rolle des Sozialarbeiters in unserem Zentrum wird beschrieben, vom Anfang seiner Arbeit kurz nach Ankunft des Pazienten. Eine vertrauensvolle Beziehung schafft sich zwischen Pazient und Sozialarbeiter während dem Aufenthalt im Krankenhaus sowie danach. Der Sozialarbeiter kümmert sich auch um die besonderen Bedürfnisse der Familie des Pazienten, der er seine geistige Unterstützung und Auskunft über legale Vorrechte, usw., gibt. Wir stellen die spezifische Sozialstruktur in Israel in Beziehung zur Rehabilitation der Benachteiligten vor, sowie die verschiedenen offiziellen Amte die ihnen Dienste leisten. Es gibt grosse Unterschiede zwischen den Diensten die durch die verschiedenen Amte geleistet werden. Die Bedürf nisse jedoch der Rückenmarkverletzten bleiben die selbe, unabhängig vom Grund der Verletzung, und deshalb ist die Aufgabe des Sozialarbeiters besonders schwer. 